HANS HAUG

In cooperation with

Hans-Peter Gasser, Françoise Perret

and Jean-Pierre Robert-Tissot

\title{
HUMANITY FOR ALL
}

\section{The International Red Cross and Red Crescent Movement}

\author{
With forewords by \\ Cornelio Sommaruga and \\ Mario Villarroel Lander
}

The forthcoming book sets out to give an accurate and suitably documented account of the International Red Cross and Red Crescent Movement. Unlike most of the works already published on the subject, which are mainly devoted to specific aspects of the Movement, the intention here is to present it in its entirety. The instruments of international humanitarian law, initiated and promoted by the ICRC, are also extensively discussed.

The author, Hans Haug, was a professor of public law, in particular public international law, at the St. Gallen University for Economics, Law and Social Sciences between 1967 and 1986, President of the Swiss Red Cross and VicePresident of the Intemational Federation of Red Cross and Red Crescent Societies between 1968 and 1982 and a member of the International Committee of the Red Cross between 1983 and 1991 . He begins by examining the various components of the Movement (the International Committee of the Red Cross, the National Red Cross and Red Crescent Societies, the International Federation of Red Cross and Red Crescent Societies), the seven Fundamental Principles of the International Red Cross and Red Crescent Movement, and international humanitarian law. Other subjects covered are the Red Cross and Red Crescent as a factor of peace, the cooperation of the components of the Movement with other national and international organizations, and the Red Cross and Red Crescent Movement and human rights.

This book is published by the Henry Dunant Institute, Geneva, and Paul Haupt Publishers, Bem/Stuttgart/Vienna. It appeared in German in 1991 and in French in 1992 (see review by Anton Schlögel in IRRC, No. 287, MarchApril 1992, pp. 202-205).

Orders should be sent to the Henry Dunant Institute, 114 rue de Lausanne, CH-1202 Geneva, Switzerland (price: 48 Swiss francs). 


\section{READ AND ENCOURAGE OTHERS TO READ THE INTERNATIONAL REVIEW OF THE RED CROSS \\ Help increase its circulation}

\section{SUBSCRIPTION FORM}

I should like to subscribe to the International Review of the Red Cross for 1 year from (date)

$\square$ English

Arabic $\quad \square$ Spanish
$\quad \square$ German (selected articles)

$\square$ French

Name

First name

Organization

Profession or function

Address

Country

Please cut out or photocopy and mail to:

International Review of the Red Cross

19, av. de la Paix

CH-1202 Geneva

English, French, Spanish and Arabic editions:

1-year subscription (6 issues): Sw. frs. 30 or US\$ 18.

(single copy Sw. frs. 5)

German edition:

1-year subscription (6 issues): Sw. frs. 10 or US\$ 6.

(single copy Sw. frs. 2)

Postal cheque account No. 12-1767-1 Geneva

Bank account No. 129.986.0, Swiss Bank Corporation, Geneva

Specimen copy on request

Date

Signature 
The International Review of the Red Cross is the official publication of the International Committee of the Red Cross. It was first published in 1869 under the title "Bulletin international des Sociétés de secours aux militaires blessés", and then "Bulletin international des Sociétés de la Croix-Rouge".

The International Review of the Red Cross is a forum for reflection and comment and serves as a reference work on the mission and guiding principles of the International Red Cross and Red Crescent Movement. It is also a specialized journal in the field of international humanitarian law and other aspects of humanitarian endeavour.

As a chronicle of the international activities of the Movement and a record of events, the International Review of the Red Cross is a constant source of information and maintains a link between the components of the International Red Cross and Red Crescent Movement.

The International Review of the Red Cross is published every two months, in four main editions:

French: REVUE INTERNATIONALE DE LA CROIX-ROUGE (since October 1869)

English: INTERNATIONAL REVIEW OF THE RED CROSS (since April 1961)

Spanish: REVISTA INTERNACIONAL DE LA CRUZ ROJA (since January 1976)

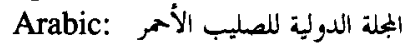

$$
\text { (since May-June 1988) }
$$

Selected articles from the main editions have also been published in German under the title Auszüge since January 1950.

EDITOR: $\quad$ Jacques Meurant, D. Pol. Sci.

ADDRESS: International Review of the Red Cross

19 , avenue de la Paix

1202 Geneva, Switzerland

SUBSCRIPTIONS: one year, 30 Swiss francs or US\$ 18

single copy, 5 Swiss francs

Postal cheque account No. 12 - 1767-1 Geneva

Bank account No. 129.986.0, Swiss Bank Corporation, Geneva

The International Committee of the Red Cross (ICRC) and the International Federation of Red Cross and Red Crescent Societies, together with the National Red Cross and Red Crescent Societies, form the International Red Cross and Red Crescent Movement.

The ICRC, which gave rise to the Movement, is an independent humanitarian institution. As a neutral intermediary in the event of armed conflict or unrest it endeavours, on its own initiative or on the basis of the Geneva Conventions, to bring protection and assistance to the victims of international and non-international armed conflict and internal disturbances and tension. 


\title{
INTERNATIONAL REVIEW
}

THE STATUTORY MEETINGS OF THE INTERNATIONAL RED CROSS AND RED CRESCENT MOVEMENT

(Birmingham, October 1993)

Resolutions of the Council of Delegates

\author{
125th ANNIVERSARY OF \\ THE DEClaRATION OF ST. PETERSBURG \\ OF 1868
}

Guiding Principles on the Right

to Humanitarian Assistance 